\title{
Characterization Of The Physical Parameters And Sampling Procedure Of A Modified Rocking Autoclave Apparatus
}

Barry E. Scheetz

Prepared for the United States

Department of Energy

Under Contract DE-AC06-77RL01030 


\section{DISCLAIMER}

This report was prepared as an account of work sponsored by an agency of the United States Government. Neither the United States Government nor any agency Thereof, nor any of their employees, makes any warranty, express or implied, or assumes any legal liability or responsibility for the accuracy, completeness, or usefulness of any information, apparatus, product, or process disclosed, or represents that its use would not infringe privately owned rights. Reference herein to any specific commercial product, process, or service by trade name, trademark, manufacturer, or otherwise does not necessarily constitute or imply its endorsement, recommendation, or favoring by the United States Government or any agency thereof. The views and opinions of authors expressed herein do not necessarily state or reflect those of the United States Government or any agency thereof. 


\section{DISCLAIMER}

Portions of this document may be illegible in electronic image products. Images are produced from the best available original document. 


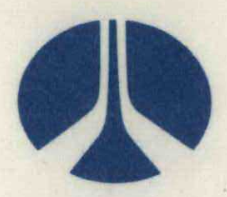

\title{
Rockwell International \\ Rockwell Hanford Operations \\ Energy Systems Group \\ Richland, WA 99352
}

\begin{abstract}
DISCLAIMER
This report was prepared as an account of work sponsored by an agency of the United States Government. Neither the United States Government nor any agency thereof, nor any of their employees, makes any warranty, express or implied, or assumes any legal liability or responsibility for the accuracy, completeness, or usefulness of any information, apparatus, product, or process disclosed, or represents that its use would not infringe privately owned rights. Reference herein to any specific commercial product, process, or service by trade name, trademark, manufacturer, or otherwise, does not necessarily constitute or imply its endorsement, recommendation, or favoring by the United States Government or any agency thereof. The views and opinions of authors expressed herein do not necessarily state or reflect those of the United States Government or any agency thereof.
\end{abstract}


RHO-BWI $-\mathrm{C}-65$

\author{
CHARACTERIZATION OF THE PHYSICAL PARAMETERS
}

AND SAMPLING PROCEDURE OF A MODIFIED ROCKING AUTOCLAVE APPARATUS

\author{
Barry E. Scheetz
}

The Pennsylvania State University

University Park, Pennsylvania 16802

\title{
Apri 1980
}

Prepared for Rockwell Hanford Operations

A Prime Contractor to the U.S. Department of Energy Under Contract Number DE-AC06-77RL01030

This report was prepared as an account of work sponsored by an agency of the United States Government. Neither the United States Government nor any agency thereof, nor any of their employees, makes any warranty, express or implied, or assumes any legal liability or responsibility for the accuracy, completeness, or usefulness of any information, apparatus, product, or process disclosed, or represents that its use would not infringe privately owned rights. Reference herein to any specific commercial product, process, or service by trade name, trademark, manufacturer, or otherwise, does not necessarily constitute or imply its endorsement, recommendation, or favoring by the United States Government or any agency thereof. The views and opinions of authors expressed herein do not necessarily state or reflect those of the United States Government or any agency thereof.

Materials Research Laboratory

The Pennsylvania State University University Park, Pennsylvania 16802 


\section{CONTENTS}

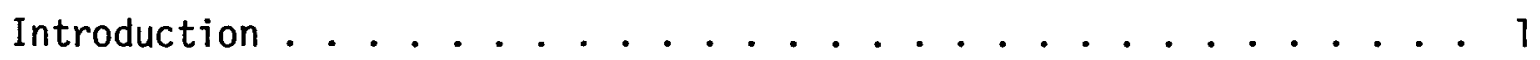

Experimental Procedures . . . . . . . . . . . . 2

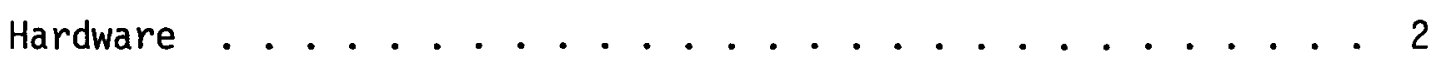

Evaluation Procedures .............. 3

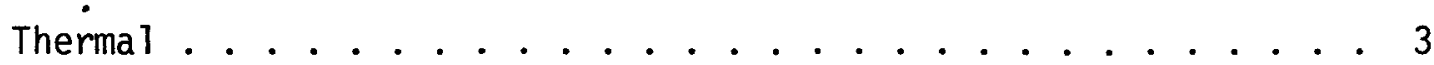

Pressurized Sampling .............. . . 5

References ................. 7

Distribution .................. . . 8

Figures:

1. The Rocking Autoclave Apparatus .............. 2

2. A Typical Data Set Obtained from the Comparison Between an Internally and Externally Placed Thermocouple on the Rocking Autoclave Apparatus .............. 4

Table:

1. Solution Analysis .............. 6 
RHO-BWI -C -65

CHARACTERIZATION OF THE PHYSICAL PARAMETERS AND SAMPLING

PROCEDURE OF A MODIFIED ROCKING AUTOCLAVE APPARATUS

\section{INTRODUCTION}

Contract research programs (fiscal years 1978 and 1979) designated to investigate the stability of several candidate nuclear waste forms under thermal and pressure regimes relevant to deep geological disposal have established that significant partitioning of cations between new solid phases and the liquid phase in contact with the simulated waste does occur. These experimental studies have in the past relied upon hydrothermal experimentation to achieve the relevant temperature and pressure conditions. The experimental design involved static, closed system experiments from which the liquids were sampled after a thermal and pressure quench. The initial experiments were designed to provide data relevant to the formation of new solid phases and the compositions of the liquids in contact with these assemblages. It was appreciated (1) that a limitation of the experimental design employed in these studies involved the precipitation of phases (with subsequent solution concentration changes) during the thermal cooling period. The solution data(2) thus obtained therefore represented, under the best circumstances, minimal values for endothermic heat of solution reactions and maximal values for exothermic heat of solution reactions. These experiments were not designed for use with theoretical models.

To obtain solution concentration data that are applicable to transport modeling, the solutions need to be sampled at temperature and pressure for complete elemental analysis of both the liquid and of solids that may form. This total elemental analysis thus should represent the solution composition that was present at temperature. This approach does not, however, include gaseous phases. 


\section{EXPERIMENTAL PROCEDURES}

\section{HARDWARE}

The rocking autoclave (Figure 1) that was modified for these new experiments was an American Instrument Company ${ }^{A}$ (AMICO) Microreactor Series apparatus. This consisted of a $300 \mathrm{ml}$ vessel of unknown composition that was heated with a conventional resistance heating element. During operations the furnace and vessel are continually pivoted normal to a point midway along the cylindrical axis of the furnace at a rate of 36 cycles per minute and through an angle of plus and minus $15^{\circ}$.

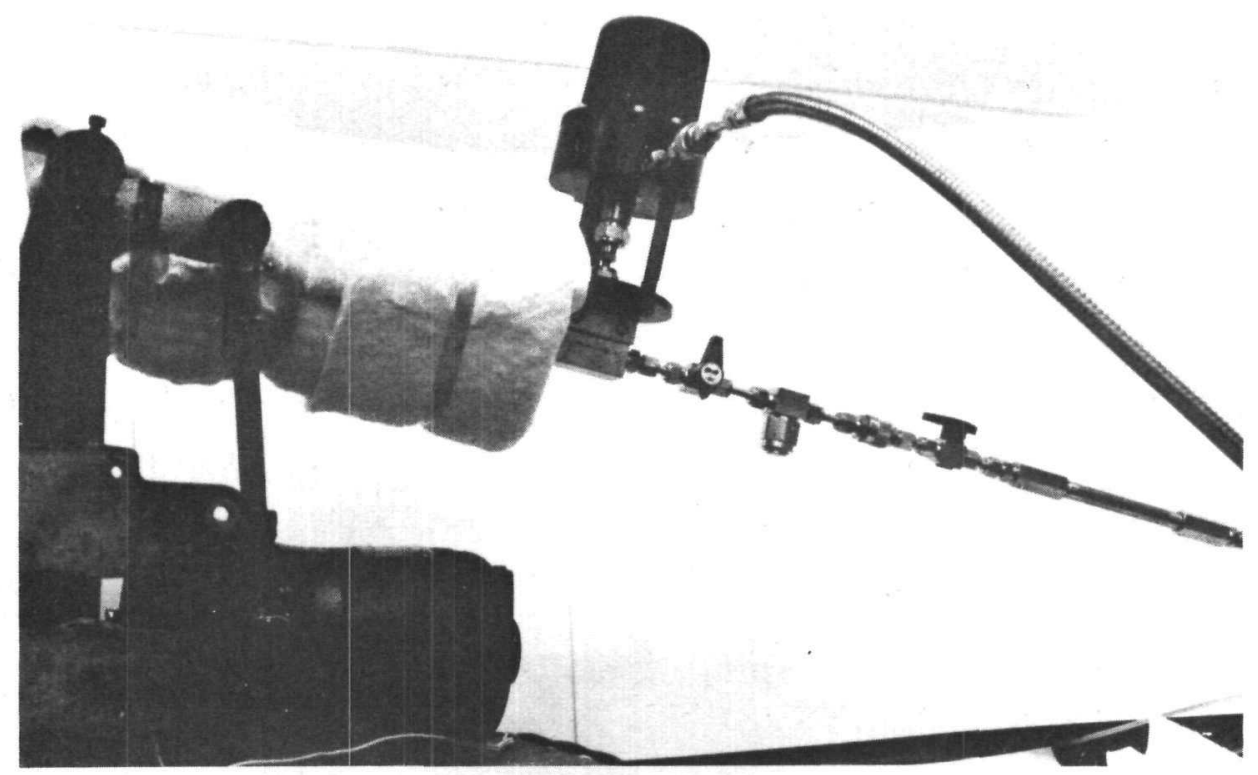

FIGURE 1. The Rocking Autoclave Apparatus.

The vessel was plated to provide an inert inner surface. The plating was accomplished by a speciality company by honing the interior of the vessel followed by sand blasting in preparation for the electrolytic deposition of a chromium metal layer $2 \mathrm{mils}(5 \mu \mathrm{m})$ thick. The plating company (Jersey Chrome Plating Company) ${ }^{B}$ experienced difficulty in achieving an acceptable coating because of the unknown nature of the alloy. To achieve an acceptable coating required some experimentation on their part and this experimentation has not been completely documented. 
The sampling system of the AMICO apparatus was abandoned and replaced with a SNO-TRIK air-operated, normally closed valve equipped with high temperature packings. In series with the pneumatically operated valve are a Teflon-coated block valve, an inline NUPRO ${ }^{C}(2 \mu \mathrm{m})$ stainless steel filter, and a SWAGELOK ${ }^{C}$ full-flow female quick-connect. The sample container consists of a HIGH PRESSURE EQUIPMENT COMPANY ${ }^{\mathrm{D}} 6 \mathrm{cc}$ micro series reactor that was lined with a Teflon sleeve. The sampling container is equipped with Teflon-lined block valves at either end and at the male quick-connect.

Through the access connector in the bottom of the vessel, a Pneu-Hydro ${ }^{E}$ resetting, backpressure-regulator valve that is adjustable and a rupture disc were added for overpressure safety. The backpressure regulator was adjusted to $30 \mathrm{MPa}$ by comparison against a dead-weight testing apparatus. This feature allows for the vessel to self-pressurize as the temperature of the vessel is raised. For added protection a rupture disc designed to fail at $56.7 \mathrm{MPa}$ was connected in parallel.

Additionally through this access connection, an interior thermocouple and/or a solution replenishment system can be added.

\section{EVALUATION PROCEDURES}

\section{THERMAL}

The initial design modifications of this apparatus did not accommodate an internal thermocouple for use during the experiment. This feature required that carefully determined temperature measurements between the interior and exterior of the vessel be made. Figure 2 contains partial data for four experimental determinations of internal vs. external temperature. Through the temperature interval from about $150^{\circ}$ to $300^{\circ} \mathrm{C}$ a rigorous straight line can be fitted to the data; however, 


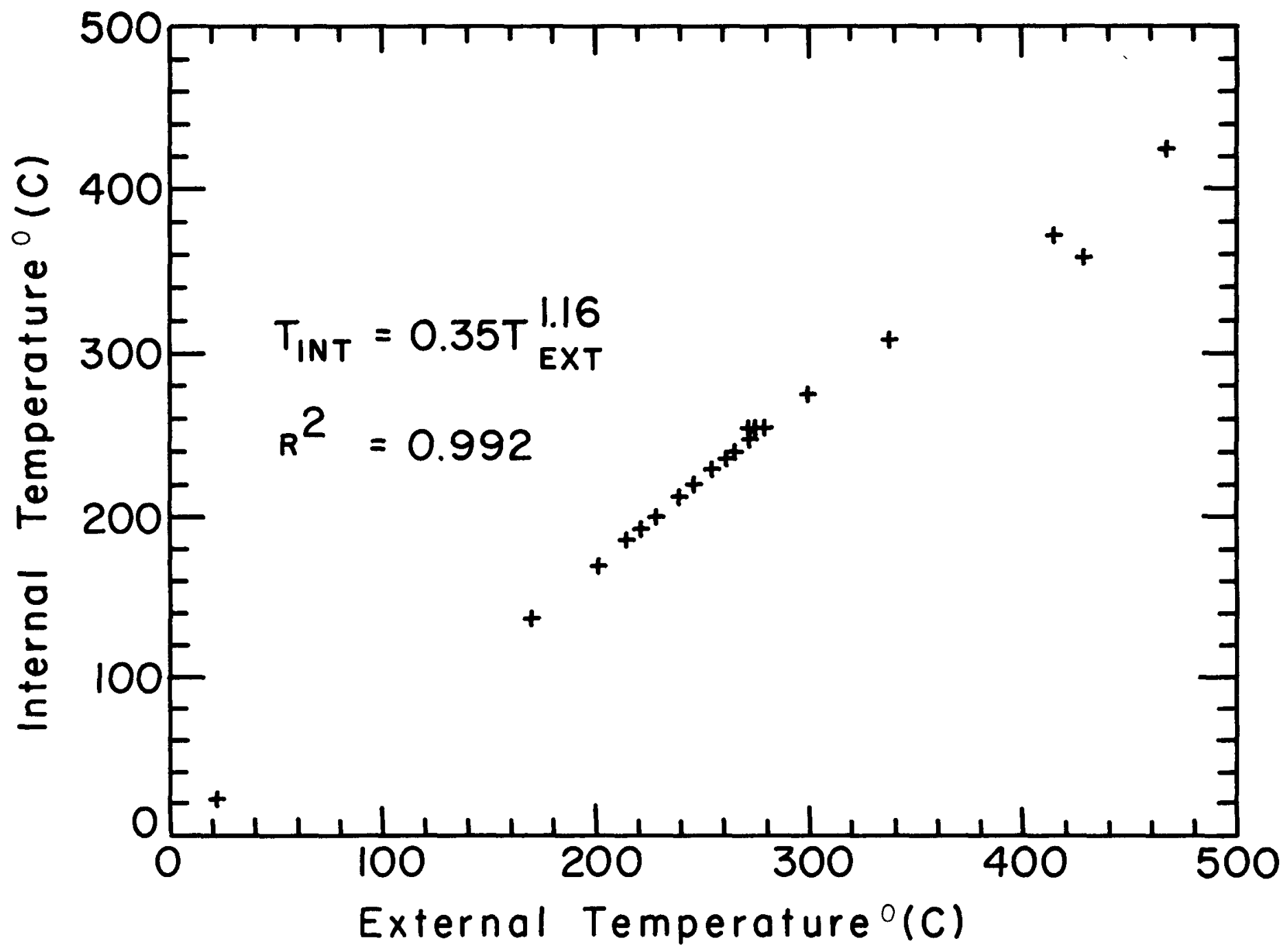

FIGURE 2. A Typical Data Set Obtained from the Comparison Between an Internally and Externally Placed Thermocouple on the Rocking Autoclave Apparatus. 
at $300^{\circ} \mathrm{C}$ a break in slope occurs with subsequent deviation from the former straight line curve fit. These data were fitted to a power curve of the form:

$$
\begin{aligned}
T_{\text {INT }} & =0.35 T_{\text {EXT }}^{1.16} \\
R^{2} & =0.992 .
\end{aligned}
$$

In the intermediate temperature range (up to $300^{\circ} \mathrm{C}$ ) the error in the measurements is estimated to be $\pm 3^{\circ} \mathrm{CC}$ and in the range from $300^{\circ}$ to $400^{\circ} \mathrm{C}$ is estimated to be $+5^{\circ} \mathrm{C}$.

During subsequent pressure testing at temperature, this type $k$ thermocouple failed and was replaced. It was observed that the replacement type $K$ thermocouple possessed an entirely different set of thermal characteristics than were previously measured. For this reason, and to maintain consistency, it was deemed necessary to maintain an internal thermocouple through all experimental runs.

\section{PRESSURIZED SAMPLING}

The goal of the pressurized testing of the modified apparatus was to evaluate the effectiveness of the sampling method. The operation of the newly designed and constructed sampling system was tested by charging the autoclave with deionized water and pressurizing it at room temperature. It performed according to expectations. The second step in the procedure was to raise the temperature to the operating range and repeat the sampling. This too was accomplished according to expectations. The volume of the liquid sampled amounted to $3.3 \pm 0.06 \mathrm{ml}$ for six samples.

The final step in the procedure was to conduct an experiment with an aqueous sample for chemical analysis. The liquid chosen for this experiment was a $15 \mu \mathrm{g} / \mathrm{ml}$ solution of $\mathrm{Sr}\left(\mathrm{NO}_{3}\right)_{2}$ adjusted from $\mathrm{pH} 1$ to an unbuffered $\mathrm{pH}$ of 4.0 with 1 molar $\mathrm{NH}_{3} \cdot \operatorname{Sr}\left(\mathrm{NO}_{3}\right)_{2}$ was used as an internal monitor of the solution. It was also chosen because of the ease and precision of detection with atomic emission spectroscopic techniques. 
The autoclave was rocked for 145 hours at $350^{\circ} \mathrm{C}$ and sampled. The solution data presented in Table 1 are somewhat surprising. The top line data represent the solution analysis for the sampled fluid while the bottom line represents the chemical analysis for the cumulative amount of solution expelled from the vessel as it pressurized.

The chemical analysis of the sampled solution indicates appreciable amounts of the constituents of the exposed stainless steel, a significant reduction in the concentration of the spiked $\mathrm{Sr}$, and an unusually high concentration of $\mathrm{Si}$. The loss of $\mathrm{Sr}$ in the sample compared with the initial solution can be accounted for by sorption onto the interior surface of the vessel, an unexpected result or by subsequent precipitation of Sr phase. The varying amounts of the components of stainless steel (including $\mathrm{C} r$ ) are accountable from the approximate $10 \%$ of exposed stainless steel pressure tubing (the tubing bore was not plated). The high concentration of silica, however, is quite unexpected. At this point, the only possible explanation for the presence of $\mathrm{Si}$ is the possibility that residual sand grains from the sand-blasting step remained inbedded in the steel vessel and were leached by the hydrotherma 7 fluids which penetrated a porous $\mathrm{Cr}$ plating. If a grain of sand used in the sand blasting procedure was assumed to have a mass of $5 \mathrm{mg}$, then this observed concentration of $S i$ could be accounted for by less than 7 such grains. It is remarkable that this much $S i$ was still detectable even after the initial pressurized sampling tests with deionized water.

Continued efforts will be directed to identifying the source of the Si detected in solution and toward the identification of the sorptive capability of the vessel toward Sr.

TABLE 1. Solution Analysis $(\mu \mathrm{g} / \mathrm{ml})$.

\begin{tabular}{l|c|c|c|c|c|c}
\hline & $\mathrm{Fe}$ & $\mathrm{Cr}$ & $\mathrm{Ni}$ & $\mathrm{Si}$ & $\mathrm{Sr}$ & $\mathrm{pH}$ \\
\hline Sample & $7.42+0.05$ & $2.33 \pm 0.02$ & $0.15 \pm 0.02$ & $125 \pm 5$ & $1.88 \pm 0.01$ & 7 \\
Overflow & $0.03 \pm 0.01$ & $0.41 \pm 0.02$ & $0.24 \pm 0.02$ & $10.3 \pm 0.1$ & $0.44 \pm 0.01$ & 4.5 \\
\hline
\end{tabular}


A. American Instrument Company

Division of Travenol Laboratories, Inc.

Silver Spring, Maryland 20910

B. Jersey Chrome Plating Company

144 4th St.

Pittsburgh, Pennsylvania 15201

C. Distributed by

Pittsburgh Valve and Fitting Co.

49 Meade Ave.

P0 Box 4155

Bellevue

Pittsburgh, Pennsylvania 15202

D. High Pressure Equipment Company, Inc.

1322 Linden Ave.

Erie, Pennsylvania 16506

E. Pneu-Hydro Products

Hibernia Ave.

Rockaway, New Jersey 07866

\section{REFERENCES}

(1) McCarthy, G. J., Scheetz, B. E., Komarneni, S., and Smith, D. K., "Reaction of Water with a Simulated High-Level Nuclear Waste Glass at $300^{\circ} \mathrm{C}, 300$ Bars," RHO-BWI-C-35, Rockwell Hanford Operations, Richland, Washington, 1978.

(2) Seyfried, W. E., Jr. and Bischoff, J. L., "Low Temperature Basalt Alteration by Seawater: An Experimental Study at $70^{\circ} \mathrm{C}$ and $150^{\circ} \mathrm{C}$." Geochimica et Cosmochimica Acta, Vo1. 43, pp. 1937 - 1947, 1979. 
Number of Copies

1

4

AGNS-BARNWELL

L. Godfrey

ARGONNE NATIONAL LABORATORY

K. F. Flynn

A. M. Friedman

M. Seite

M. J. Steindler

BATTELLE-OFFICE OF NUCLEAR WASTE ISOLATION

S. J. Basham

A. A. Bauer

H. B. Brugger

F. L. Burns

J. A. Carr

N. E. Carter

M. Kahnemuyi

Library (5)

BECHTEL INCORPORATED

R. A. Langley, Jr.

BROOKHAVEN NATIONAL LABORATORY

P. W. Levy

BROWN UNIVERSITY

B. Giletti

N. Rutherford

CAL IFORNIA ENERGY RESOURCES CONSERVATION

AND DEVELOPMENT COMMISSION

E. Varanini

CORNING GLASS WORKS

M. G. Britton

D'APPOLONIA CONSULTING ENGINEERS, INC.

D. A. Davenport

R. D. Ellison

D. Stephanson

J. Wright (2) 
Number of Copies

5 GEOLOGY OVERVIEW COMMITTEE

T. Livingston

I. Remson

H. Ross

D. A. Swanson

W. S. Twenhofe 1

1

HANFORD ENGINEER ING DEVELOPMENT LABORATORY

D. A. Cant ley

HAHN MEITNER INSTITUTE

W. Lutze

1

HARWELL LABORATORY

N. A. Chapman

HYDROLOGY OVERVIEW COMMITTEE

P. Domenico

W. W. Dudley, Jr.

R. A. Freeze

P. M. Grimstad

S. P. Newman

F. L. Parker

J. Pearson

1

KAISER ENGINEERS, INC.

J. S. Ritchie

4

LAWRENCE BERKELEY LABORATORY

J. A. Apps (2)

L. V. Benson

P. A. Witherspoon

3

LAWRENCE LIVERMORE LABORATORY

L. G. Ballou

A. G. Duba

L. D. Ramspott

5

LOS ALAMOS SCIENTIFIC LABORATORY

K. E. Apt

R. W. Charles

G. A. Cowan

B. R. Erdal

K. Wolfsberg 
RHO-BWI - C-65

Number of

Copies

4

NATIONAL ACADEMY OF SCIENCES

W. E. Berg

D. Daley

J. Pomeroy

S. Stuen

18

NATIONAL ACADEMY OF SCIENCES -

COMMITTEE ON RADIOACTIVE WASTE MANAGEMENT

M. Baram

S. N. Davis

E. L. Draper

P. W. Durbin

J. T. Edsall

M. Eisenbud

J. A. Fay

J. C. Frye

H. L. James

R. E. Kasperson

K. B. Krauskopf

T. R. LaPorte

C. Mawson

F. L. Parker

T. Pigford

R. Roy

E. Wenk, Jr.

1

NATIONAL BUREAU OF STANDARDS

T. Hahn

NATIONAL RADIOLOGICAL PROTECTION BOARD

M. D. Hill

NORTH DAKOTA STATE UNIVERSITY

G. J. McCarthy

6

OAK RIDGE NATIONAL LABORATORY

C. F. Baes, Jr.

G. W. Beall

J. 0. B lomeke

F. W. Dickson

H. W. Godbee

J. G. Moore 
\begin{tabular}{c} 
Number of \\
Copies \\
\hline
\end{tabular}

2

OREGON STATE UNIVERSITY

Department of Chemistry

Department of Geology

11

PACIF IC NORTHWEST LABORATORY

D. J. Bradley

H. Fullman

0. F. Hill

J. L. McElroy

J. E. Mendel

W. A. Ross

J. M. Rusin

R. J. Serne

D. M. Strachan

J. H. Westsik

Library

THE PENNSYLVANIA STATE UNIVERSITY

D. M. Roy

R. Roy

B. E. Scheetz (5)

ROCK MECHANICS OVERVIEW COMMITTEE

N. G. Cook

J. W. Corwine

W. Hustrulid

A. A. Mathews

J. Russell

\section{SANDIA LABORATORIES}

E. H. Beckner

C. L. Christensen

F. A. Donath

R. G. Dosch

J. L. Krumhans 1

A. Lappin

R. C. Lincoin

W. C. Luth

R. W. Lynch

M. A. Molecke

P. D. O'Brien

E. J. Nowak

A. E. Stephenson

L. D. Tyler

W. D. Weart 
Number of Copies

1

1

1

1

1

1

1

1

2

2

1

3
SAVANNAH RIVER LABORATORIES

C. E. Bailey

SCIENCE APPLICATIONS, INC.

D. H. Lester

STANFORD RESEARCH INTERNATIONAL

R. Lohman

STATE OF IDAHO GOVERNOR'S OFF ICE

C. Jones

STATE OF OREGON GOVERNOR'S OFFICE

K. Woods

STATE OF WASHINGTON GOVERNOR'S OFFICE

J. Wood

SWEDISH NUCLEAR FUEL SUPPLY COMPANY (KBS)

L. B. Nilsson

UNIVERSITY OF ARIZONA

J. J. Daemen

UNIVERSITY OF COLORADO

D. D. Runnels

Library

UNIVERSITY OF MISSOURI

S. E. Manahan

Library

UNIVERSITY OF NEW MEXICO

D. G. Brookins

UNIVERSITY OF WASHINGTON

Department of Chemistry

Department of Geology

Library 
D. T. Schueler

U.S. DEPARTMENT OF ENERGY-COLUMBUS PROGRAM OFFICE

M. Barainca

J. 0. Neff

4

U.S. DEPARTMENT OF ENERGY-HEADQUARTERS

C. R. Cooley

C. H. George

C. A. Heath

D. L. Vieth

1

U.S. DEPARTMENT OF ENERGY-NEVADA OPERATIONS OFFICE

R. M. Nelson

U.S. DEPARTMENT OF ENERGY-PUBLIC READING ROOMS

Richland, Washington

Seattle, Washington

6

U.S. DEPARTMENT OF ENERGY-RICHLAND OPERATIONS OFFICE

T. A. Bauman

R. B. Goranson

A. G. Lassila

B. L. Nicoll

D. J. Squires

F. R. Standerfer

U.S. GEOLOGICAL SURVEY

G. D. DeBuchananne

P. R. Steven

6

U.S. NUCLEAR REGULATORY COMMISSION

R. R. Boyle

J. 0. Bunting, Jr.

J. D'Ambrosia

J. C. Malaro

J. B. Martin

E. P. Regnier

WASHINGTON PUBLIC POWER SUPPLY SYSTEM, INC.

D. D. Tillson 
RHO-BWI -C-65

Number of

Copies

1

WASHINGTON STATE DEPARTMENT OF ECOLOGY

Library

1

WASHINGTON STATE DEPARTMENT OF NATURAL RESOURCES

Library

WASHINGTON STATE UNIVERSITY

Department of Chemistry

Department of Geology

Library

1 WATERWAY EXPER IMENT STATION

K. Mather

1

A. C. WATERS

2

WESTINGHOUSE WIPP PROJECT

R. C. Mairson

WOODWARD-CLYDE CONSULTANTS

H. Ewoldsen

M. R. Niccum

C. Taylor (3)

70 ROCKWELL HANFORD OPERATIONS

H. Babad (5)

R. L. Biggerstaff

D. J. Brown

D. J. Cockeram

W. E. Coons

T. A. Curran (5)

R. A. Deju

H. B. Dietz (10)

G. C. Evans

R. J. Gimera

R. N. Gurley (10)

G. S. Hunt

R. E. Isaacson

L. P. McRae

C. W. Myers

M. J. Smith (10)

Basalt Waste Isolation Project Library (10)

Document Control (4)

Records Retention Center (2) 